\section{Eszter \\ Szedlacsek \\ Eurocrisis: The European Integration as a Neoliberal Project}

\section{Bionote}

Eszter Szedlacsek holds a degree in International Relations, and she is currently an intern in the European Parliament. She is a member of the College for Advanced Studies in Social Theory, participated in the National Conference of Scientific Students' Associations, and has worked at the Institute for Political Science at the Hungarian Academy of Sciences. Her main topics are Europeanization and critical social theories.

\section{Introduction}

The current crisis of the EU can be analysed through a variety of different theories from International Relations (IR), from sociological and policy-centred point of views. Mainstream currents, such as (neo-) constructivism, intergovernmental and supranationalist theories played a significant role in the flow of European integration, mainly with institutionalization and statecentrism in their focus. In my essay I will argue that these theories do not provide sufficient answers to the present-day crisis of the EU, but rather that embracing critical perspectives in the image of neo-Gramscian theories can provide a proper basis for analysis. Using historical materialist grounds, I will claim that European integration is a neoliberal project based on the support of a transnational capital and class, establishing a historic bloc and hegemony, integrating the EU into the world order led by the US. Understanding the EU as a project in this way enables us to examine the current crisis as a crisis of the European neoliberal project, rather than a crisis stemming from political and democratic grounds.

\section{What Are the Mainstream Theories behind European Integration?}

The idea of a "new Europe," or in other words, the basis for the organization that we know as the European Union, was not a brand new concept after the war. This idea originated from the period between the two World Wars and became firm during the Second World War. Nonetheless, when Altiero Spinelli, Jean Monnet, David Mitrany, Richard Kalergi or Winston Churchill were thinking of a new alliance leading to peace throughout the European continent, they were not at all thinking of the same concept. Although the mainstream theories behind European integration included a variety of directions, they do not take into account the relations of power or social forces, which the neo-Gramscian perspectives are trying to provide an answer for.

The cornerstones of the EU laid in the post-World War situation, which reflected the socio-economic background and ideological-political crisis after the Second World War, but the ideas behind the continental alliance led back to the period prior to the Second World War. The deepening ties within the European Union responded to the emerging Pax Americana and the new world order, as the economic rebirth of Europe was possible based on the Marshall Plan. Although the European economy revitalized due to American help, the European Union did not develop from a fully federalist union, but on functionalist-federalist grounds. During the Second World War, federalist views started to emerge, contrasted to the Nazi ideology led by Altiero Spinelli. According to Spinelli's ideas, the main goal of an alliance would be the federalist restructuring of Europe 
that would leave nations' sovereignty behind and build a proper institutional background, in order to avoid further conflict. In contrast to this, Jean Monnet's plans sounded differently: he saw Europe's future in deepening the economic ties between states. The materialized product of Monnet's ideas, the Treaty of the European Coal and Steel Community, was ground breaking in its nature: it was the first Treaty that required abandoning a part of the national sovereignty from the participating states. ${ }^{1}$

The second period of the European integration in the 1960 s was characterised by the ongoing neo-functionalist (supranationalist) and intergovernmental debate. According to neo-functionalist theories, integration is continuously formed by advocacy of actors and groups in society, and throughout this process actors are enabled to enforce their interest in a more efficient and pragmatic way. While neo-functionalism considered integration as a somewhat automatic progress, intergovernmental theorists rejected this view. The integration process is a materialization of the interests of a sovereign state in a certain specific position, not by far considered automatic by intergovernmental views. Debates led by Spinelli and Delors resulted in signing the Single European Act and the Maastricht Treaty, which were blossoms of compromises between the intergovernmental and federalist theorists. ${ }^{2}$

1 Simon Bulmer and Jonathan Joseph, "European Integration in Crisis? Of Supranational Integration, Hegemonic Projects and Domestic Politics," European Journal of International Relations, Vol. 22, No. 4 (2015), 725-48.

2 Frank Schimmelfennig and Ulrich Sedelmeier (Eds.), The Politics of European Union Enlargement: Theoretical Approaches (London and New York: Routledge, 2009).

\section{Introducing the Neo-Gramscian Perspective}

While mainstream theories mostly deal with institutionalization, the form of the integration process, rather than the content of it, critical theories pay more attention to the social content of integration, understanding the socio-economic forces behind it. Neo-Gramscianism embraces the emphasis on the relation of social forces, the decisive role of ideologies, and abandons state centrism so typical of IR theories. The neo-Gramscian historical materialist approach, although declining economism in any sense, takes the sphere of production as a basis. Contrasted to the Marxian sense of the relations of production, Gramsci includes a wide concept of production and reproduction - knowledge, institution and cultural-social relations as well.

Production [...] is to be understood in the broadest sense. It is not confined to the production of physical goods used or consumed. It covers the production and reproduction of knowledge and of the social relations, morals and institutions that are prerequisites to the production of physical goods. ${ }^{3}$

As the ideas and role of the intellectual gain more presence than in other theories, ideologies become spheres through which world order and conflicts become associated, in which groups understand and acknowledge their position. Ideas and intellectuals are differentiated between "traditional" and "organic" in social order. Organic ideas organize the recognition of struggle and position throughout social forces, while organic intellectuals are representing a fraction of social forces. Ideas by organic intellectuals provide

3 Andreas Bieler and Adam David Morton, "A Critical Theory Route to Hegemony, World Order and Historical Change: NeoGramscian Perspectives in International Relations," Capital and Class, Vol. 28, No. 1 (2004), 85-113. 
linkage between ideologies and relations of capitalist production, offering a scene for struggle of social forces and fractions, where intellectuals can transcend the interests of the fraction they represent. In Gramscian thinking, the concept of consent plays a significant role, so historic blocs are created when dominant social forces and fractions establish their position over subordinate social forces. ${ }^{4}$

Dialectical relations of forces are used to examine the relationship between production and power. Figure 1 shows how social relations of production give rise to social forces that contribute to forms of state as a basis of power in the complexity of civil and state society, constituting and shaping world orders.

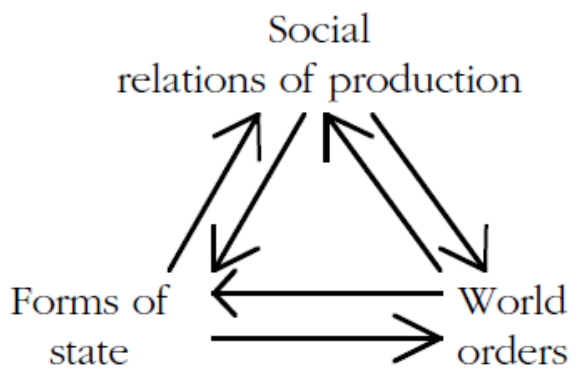

Figure 1. Dialectical relations of forces ${ }^{5}$

Neo-Gramscian theorists identify three more elements of hegemony situated under the aspects mentioned before. Thus, ideas refer to intersubjective meanings and

4 Stephen Gill (Ed.), Gramsci, Historical Materialism and International Relations (Cambridge: Cambridge University Press, 1993).

5 Adam David Morton, "Social Forces in the Struggle over Hegemony: Neo-Gramscian Perspectives in International Political Economy," Rethinking Marxism: A Journal of Economics, Culture and Society, Vol. 15, No. 2 (2003), 155. images, and material capabilities to access resources, which contribute to the creation of institutions.

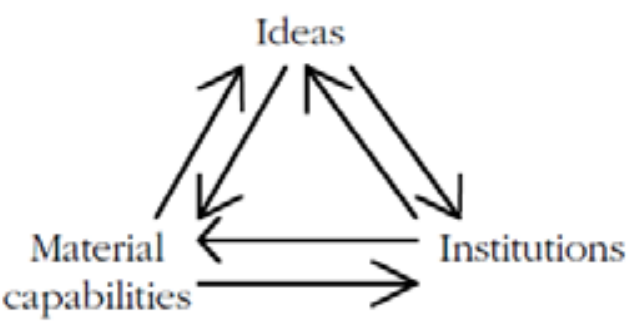

Figure 2. Dialectical moment of hegemony ${ }^{6}$

Our definition of hegemony is crucial in the understanding of the hegemony of transnational class and neoliberal capital. IR theory offers a variety of concepts of hegemony: (1) hegemony as international domination, (2) hegemony as state hegemony, (3) hegemony as consensual domination or ideological hegemony, (4) hegemony as the exercise of leadership within historic blocs within a particular world order.7 According to Cox, hegemony is "based on a coherent conjunction or fit between a configuration of material power, the prevalent collective image of world order (including certain norms) and a set of institutions which administer the order with a certain semblance of universality." I will use this notion of hegemony in my analysis of neoliberal hegemony, with the transnational capital and class establishing its position in the historic bloc.

$6 \quad$ Ibid., 156.

7 William I. Robinson, "Gramsci and Globalisation: From Nation-State to Transnational Hegemony," Critical Review of International Social and Political Philosophy, Vol. 8, No. 4 (2005), 559-74.

8 Robert W. Cox, "Social Forces, States, and World Orders: Beyond International Relations Theory," Millennium: Journal of International Studies, Vol. 10, No. 2 (1981), 126-55. 


\section{The Eastward Expansion as "Passive Revolution"}

In 2004, Cyprus, the Czech Republic, Estonia, Hungary, Latvia, Lithuania, Poland, Malta, Slovakia, and Slovenia joined the European Union as part of the EU expansion. Since then, other parts have joined, firstly Romania and Bulgaria (2007), secondly Croatia (2013). The European integration process, after a failure in deepening ties with the already participating countries, started the politics of expansion when it saw the vacuum the Sovietcommunist regimes left behind in Eastern Europe. The mainstream thinking about integration of Eastern European countries involves succession of democratic values, establishing open and free market economy and politics of development in this area. According to these theories, integration was meant to balance and equalize differences between member states' political and economic status. Instead of analysing the Eastward expansion in these terms, I will embrace the Gramscian term "passive revolution" to examine how Eastern European countries were affected by the expansion.

Gramsci identifies "passive revolution" as a project in which a new (transnational) bourgeois class is created in power structures, in which no bourgeois class or hegemony existed before. It usually includes rapid restructuring of power relations by external forces, excluding mass participation. The two fundamental principles regarding "war of movement," which Gramsci associates with passive revolution, are the following:

(1) No social formation disappears as long as the productive forces that have developed within it still find room for further forward movement.
(2) A society does not set tasks for itself if the necessary conditions for their resolution have not already been incubated, etc. ${ }^{9}$

According to Gramsci, the Marshall Plan and Americanism in Europe after the Second World War can be identified as passive revolution: introduction of capitalist production and expansion of American dominance and a new bourgeois class in the subordinated Europe. Neo-Gramscian theorists argue that European Union's Eastward expansion is another example of passive revolution, and the PHARE Program offered to Poland and Hungary after the period of existing socialism is directly comparable to the Marshall Plan in the post-World War period. ${ }^{10}$

\section{The EU and Expansion as a Neoliberal Project}

The "open market economy" and conditionality of Europe from the US began after the World War II, when the idea of Europe started to gain more ground. Conditionality, used by the US in the form of providing aid (the Marshall Plan) for Europe only in case Europe follows its "open market economy" policy, was created with a positive reward system. While this was the first generation of international conditionality, the second generation came in the 1970s. During these years, a new orthodoxy started to emerge, called the Chicago School, that was almost immediately embraced by the IMF and world leader organizations. Neoliberal aspects of market liberalization, austerity politics and financial administrative reform were all part of the macroeconomic reorganization in the 1970s. Although not a trigger, the paradigm shift of Western countries

9 Alan W. Cafruny and Magnus Ryner (Eds.), A Ruined Fortress? Neoliberal Hegemony and Transformation in Europe (Lanham, MD: Rowman and Littlefield, 2003), 56.

10 Ibid., 47-70. 
came with the fall of communism in Eastern Europe, which led to the idea of a correlation between democracy and economic development. After 1990, the EU aid massively concentrated on Eastern European countries, the aid being an external shock to the countries' emerging new economies. It's devastating effect focusing on not political, but material and economic means reflects the way the European Union's interests lay in the "new" areas. ${ }^{11}$ Aid and conditionality was well documented by European agreements with Eastern European countries, the Copenhagen Criteria and the Treaty of the European Union. Although the term conditionality is widely debated, it is mostly agreed on by literature that conditionality "is not an aim but an instrument by which other objectives are pursued." ${ }^{12}$ This suggests that conditionality mainly operates in asymmetric power relations, with the dominant over the subordinate actor. Following Gramsci's definition of "passive revolution," injecting Eastern European countries with European aid and therefore engendering conditionality can be analysed as restructuring of social power relations, in an aspect of the sphere of production. ${ }^{13}$ Therefore, the EU can be analysed as a neoliberal hegemonic project, in which newly emerging Eastern European democracies became dependent on Western European and transnational elite classes. These power relations contributed to

11 Bastiaan van Apeldoorn, Transnational Capitalism and the Struggle over European Integration (London and New York: Routledge, 2002).

12 Olav Stokke, "Aid and Political Conditionality: Core Issues and State of the Art," in Aid and Political Conditionality, ed. by Olav Stokke (London: Frank Cass, 1995), 2.

13 James Hughes, Gwendolyn Sasse and Claire Gordon, "The Logic of Enlargement Conditionality and Europeanization," in Europeanization and Regionalization in the EU's Enlargement to Central and Eastern Europe. The Myth of Conditionality, ed. by James Hughes, Gwendolyn Sasse and Claire Gordon (London: Palgrave, 2005). uneven development and ever-widening inequalities in Eastern European countries, as an inevitable cost to the European integration project - the neoliberal vision of economic success and free market economy has a price to pay in (semi-)peripheral countries. Thus, the EU now is even more widely committed to the neoliberal vision, the free market economy and development of central areas, while dismissing redistribution across member states. Loss of boundaries so often claimed to be a key feature in neoliberal hegemony is anything but true in Eastern Europe. Boundaries between East and West, "core" and "periphery," seem to even strengthen, not loosen in relation with the neoliberal project of the EU in post-Soviet countries. ${ }^{14}$ The image of a multi-speed Europe is starting to replace the concept of a single Europe that was most probably the image the Founding Fathers had in mind.

Another aspect of passive revolution is the creation of a new bourgeois class: it is often said that "the revolutions in Eastern Europe, as often stated, were bourgeois revolutions without a bourgeoisie. Instead of powerful economic groups, it was intellectuals and elites within the state who became responsible for the neoliberal reforms." ${ }^{15}$ Later, this national elite was replaced by transnational classes as a result of the restructuring of domestic social relations. It was the ERT (The European Round Table of Industrialists) that played a crucial part in European integration in the 1990s. The papers and speeches of the President of the Commission, Jacques Delors, almost in all aspects reflected the papers by ERT

14 Andreas Bieler, "The Struggle Over EU Enlargement: A Historical Materialist Analysis of European Integration," Journal of European Public Policy, Vol. 9, No. 4 (2002), 57598.

15 Dorothee Bohle, "Neoliberal Hegemony, Transnational Capital and the Terms of the EU's Eastward Expansion," Capital and Class, Vol. 30, No. 1 (2006), 57-86. 
previously. Eventually, in the Treaty of Maastricht, two major theoretical views on integration were combined: neo-mercantilist and social democratic projects, resulting in the so-called "embedded neoliberalism."16 The ERT, instead of being a union or a very strong group, brings together the organic intellectuals and provides them with a platform which enables to further create a hegemonic project and transcend their interests. ${ }^{17}$ Embedded neoliberalism could become the leading economic project bringing with it all the political ideas as well due to the great help and interests conceived by transnational capital. According to Otto Holman,

It is foreign capital - and the quasi-state structures and cadres at the supranational level organically related to it - which plays an essential role in the process of transnational class formation in CEE. The ownership and control of economically-relevant assets, and the income generating nature of it, are increasingly transnational phenomena, while the growing inequality in the distribution of these assets is defended - that is, presented as the "general interest" - by the "new power elites." 18

With transnational capital as the cornerstone of embedded neoliberal hegemony, class struggle between national capital and national labor is strengthened, inequalities are growing, and unequal development depending on localization (countryside - city) are firmed

16 Dorothee Bohle and Béla Greskovits, "Neoliberalism, Embedded Neoliberalism and Neocorporatism: Towards Transnational Capitalism in Central-Eastern Europe," West European Politics, Vol. 30, No. 3 (2007), 443-66.

17 Andreas Bieler, "Class Struggle over the EU Model of Capitalism: Neo-Gramscian Perspectives and the Analysis of European Integration," Critical Review of International Social and Political Philosophy, Vol. 8, No. 4 (2005), 513-26.

18 Bohle, "Neoliberal Hegemony." due to continuing urbanization and gentrification. ${ }^{19}$ In the historic bloc, transnational capital not only engenders struggle at the national level, but also between national capital and labor and transnational capital and labor. This contributes to the affirmation of the core-periphery relations and the dominant-subordinated positions in the Gramscian historic bloc of neoliberal hegemony. The new idea of a multi-speed Europe, instead of distribution in the single Europe, is a reinforcement of these relations. ${ }^{20}$

\section{What Are the Consequences?}

In the neoliberal expansionist project of the EU, supported highly by the transnational elite, extending the market lead by transnational class was a high priority in opposition of national and international labor. Nonetheless, the current crisis of the neoliberal hegemony and historic bloc and its leading class and capital, is coming from the inequalities created by the historic bloc itself. The false idea that economic liberation is strongly interrelated to democratization and democratic legitimacy caused the unequal development of the core and periphery, and thus, the passive consent of people is starting to disappear. The eurocrisis originating in the differences in economic status of several states compared to those at the centre, is causing a social economic crisis, too, that leads to Euroscepticism and loss of democratic legitimacy of the EU. The political and democratic crisis of the EU is

19 John Agnew, "How Many Europes? The European Union, Eastward Enlargement and Uneven Development," European Urban and Regional Studies, Vol. 8, No. 1 (2001), 29-38.

20 Andreas Bieler and Adam David Morton, Social Forces in the Making of the New Europe: The Restructuring of European Social Relations in the Global Political Economy (London: Palgrave, 2001). 
stemming from its core structure in creating a historic bloc with all its components. As identified in Gramscian theory explained before, ideas, material capabilities and institutions play crucial role in establishing the main components of hegemony and historic bloc. ${ }^{21}$

21 Bastiaan van Apeldoorn, "The Eurocrisis and the Crisis of Neoliberal Europe: Dilemmas For Europe's Transnational Corporate Elite," Corporate Europe Observatory, April 23, 2012, www.corporateeurope.org/eu-crisis/2012/o4/eurocrisisand-crisis-neoliberal-europe-dilemmas-europe-transnationalcorporate. 